\title{
Effects of dietary supplementation with peony pollen on growth, immune-related gene expression, and antioxidant status of Cyprinus carpio
}

\author{
Hong tao Ren*, Yong Huang, Xiao chan Gao, Shi yang Gao \\ Animal Science and Technology College, Henan University of Science and Technology, \\ Luoyang 471003, China
}

Key words: peony pollen, common carp, immune genes, antioxidant enzymes

\begin{abstract}
Peony (Paeonia suffruticosa Andr.) is both ornamental flower and Chinese herbal medicine in China. This study was conducted to investigate the effects of dietary peony pollen on growth performance and immune status of common carp (Cyprinus carpio). Five different diets with $0 \%$ (control group), 1\%, 2\%, $3 \%$ and $4 \%$ of peony pollen were designed to feed the fish for 6 weeks. The results indicated that the dietary peony pollen has beneficial effects on growth performance of common carp. In addition, evaluation of the liver antioxidant enzymes activity of total antioxidant capacity (T-AOC), glutathione peroxidase (GPX), superoxide dismutase (SOD) and catalase (CAT) in $3 \%$ peony pollen group, showed significant increase in carps fed peony pollen $(P<0.05)$, except the malondialdehyde (MDA) activity. The genes expression levels of tumor necrosis factor-a (TNF-a), transforming growth factor- $\beta$ (TGF- $\beta$ ) and interleukin-1- $\beta$ (IL1 $\beta$ ) in the carps fed peony pollen were obviously decreased compared to the control group $(P<0.05)$. The expression levels of heat shock protein-70 (Hsp70) were up-regulated significantly in carps fed peony pollen ( $P$ $<0.05$ ). Our observations suggest that peony pollen supplementation in the diets has the potential to improve the immune response by activating carp's cellular antioxidant activity and regulating the expression of immune -related genes, which may lead to increased carp tolerance to adverse conditions. Further research is needed on the use of peony pollen to improve disease resistance in fisheries.
\end{abstract}

\footnotetext{
* Corresponding author. e-mail: hthn2020@163.com
} 


\section{Introduction}

Aquatic industry provides a rich source of protein for the people food, which is growing rapidly in developing countries (Naylor et al., 2000). With the development of aquaculture, the density of farmed fish is getting higher and higher. The rearing conditions are also getting worse. Adverse feeding conditions may have a negative impact on the immunity of the fish and may result in infection by natural microorganisms (Van et al., 2017). Under such circumstances, antibiotics and drugs were used to resistance to infectious diseases (Cañada-Cañada et al., 2009). Excessive use of drugs and antibiotics for the treatment of diseases in fish production systems leads to enrichment of aquaculture environment and fillets, Inhibition of the antibiotic resistance and immune system (Van Hai, 2015). Due to issues related to residual antibiotics, attention to the harmful effects of antibiotics on the environment and human health has led to the development of safe alternatives, such as probiotics, prebiotics and immunostimulants (Makkar et al., 2005; El-Haroun et al., 2006; Dawood and Koshio, 2016; Ramos et al., 2017). The consequences of this have impeded the sustainable development of aquaculture. Therefore, there is an urgent need to find new strategies for dealing with pathogen infections. In recent years, traditional Chinese medicine, herbal extracts and plant-derived commercial products have been used in aquaculture, which is an effective method to improve the effect of aquaculture (Van Hai, 2015). Safer, more environmentally friendly herbal medicinal products offer a potential alternative to antibiotics and chemicals drugs (Galina et al., 2009). Herbal medicinal products have been studied in mice, human and other animals, and used as feed additives for aquaculture. Some herbal medicinal products studied in carps have been reported, such as Ginkgo biloba leaf extract, Astragalus root, Angelica sinensis root (Bao et al., 2019; Bulfon et al., 2015; Jian and $\mathrm{Wu}, 2004$ ). These findings indicate that herbal products can improve disease resistance.

Peony has been cultivated in Luoyang region of central China since ancient times and is rich in peony pollen resources, and there is a special oil peony for the production of peony seed oil, its flowers can be used as a by-product for other industries. Peony is a natural edible, medicinal and ornamental non-toxic plant, which has a "King of flowers" reputation, peony pollen is rich in amino acids and vitamins, containing a large number of health-care functions of polysaccharides. Flavonoid is one of the most important nutrients in peony pollen, containing a variety of increased physiological activity, anti-aging, antioxidant, with the ability to improve their own immunity (Liu et al., 2012; Yuan et al., 2013).

Up to now, little information has been reported on the application of peony pollen in fishery production. Therefore, it is necessary to develop and utilize peony pollen as a new active substance in aquaculture. In the study, the hypothesis was that the supplement of peony pollen to carp diets would lead to beneficial effects on antioxidant defense and immune response of carp. Common carp (Cyprinus carpio) as one of the most widely distributed freshwater fish in the world, been reared in China for thousands of years (Sharma and Leung, 2000). To our knowledge, there is no public data on the effects of peony pollen on common carp. Thus, this study aimed to investigate the possible effects of peony pollen on carp growth performance, antioxidant defense, and immune response.

\section{Materials and Methods}

\section{Fish and experimental conditions}

All experimental procedures were approved by the Bioethical Committee of Henan University of Science and Technology.

Experimental fish come from a local carp breeding base in Luoyang, Henan, China. All fish were kept in five 500L tanks for 2 weeks to acclimatize. During the experimental trials, carps $(110 \pm 2 \mathrm{~g})$ were selected randomly and cultured in 15 tanks. Each diet group was assigned three replicates, each replicates has 20 fish. The fish were fed a basic diet for 14 days to adapt to the experimental conditions before the test, and the trial was conducted for 6 weeks. Experimental fish were fed twice daily at 8:30 and 14:30 (3\% of body weight, 
and weighted every 2 weeks to adjust feeding rate. During the trial, the water in the storage tank was continuously aerated by aerator and $50 \%$ water was changed in experimental tank every three days. To measure water quality index regularly to ensure that it is within the range of safe cultivation.

\section{Feed preparation}

In order to determine the effect of peony pollen on common carp, five different diets were designed as the basic diet with $0,10,20,30$ and $40 \mathrm{~g}$ of peony pollen added per $\mathrm{kg}$ of feed. The feed formula is shown in Table 1. Peony pollen is collected from the peony park, Luoyang, China, then quickly dried and made into a powder for preservation at -20 ${ }^{\circ} \mathrm{C}$. A laboratory feed mixer was used to mix the feed ingredients and a miniature granulator was used to make the feed into $2 \mathrm{~mm}$ pellets. The dry feed is stored at $-20^{\circ} \mathrm{C}$.

Table 1 Composition and nutrient levels of experimental diets.

\begin{tabular}{llllll}
\hline \multirow{2}{*}{ Ingredients (\%) } & \multicolumn{2}{l}{ peony pollen level } & & \\
\cline { 2 - 6 } & $0 \%$ & $1 \%$ & $2 \%$ & $3 \%$ & $4 \%$ \\
\hline Fish meal meal & 10 & 10 & 10 & 10 & 10 \\
Soybean meal & 26 & 26 & 26 & 26 & 26 \\
Rapeseed meal & 25 & 25 & 25 & 25 & 25 \\
Wheat flour & 21 & 20 & 19 & 18 & 17 \\
wheat bran & 10 & 10 & 10 & 10 & 10 \\
Fish oil & 1 & 1 & 1 & 1 & 1 \\
Soybean oil & 1 & 1 & 1 & 1 & 1 \\
Choline chloride & 1 & 1 & 1 & 1 & 1 \\
Calcium biphosphate & 2 & 2 & 2 & 2 & 2 \\
Mineral premix & 2 & 2 & 2 & 2 & 2 \\
Vitamin premix & 1 & 1 & 1 & 1 & 1 \\
Peony pollen & 0 & 1 & 2 & 3 & 4
\end{tabular}

Approximate composition

$\%$

\begin{tabular}{llllll} 
Dry matter & 88.2 & 87.9 & 89.4 & 89.7 & 87.8 \\
Crude protein & 35.2 & 34.8 & 35.7 & 34.9 & 35.6 \\
Crude lipid & 4.15 & 4.08 & 4.32 & 4.24 & 4.16 \\
Ash & 9.8 & 10.1 & 10.2 & 9.9 & 10.5 \\
\hline
\end{tabular}

aMineral premix consisted of $(\mathrm{g} / \mathrm{kg}$ of premix): aluminum chloride, 0.45 ; cobalt chloride, 0.2 ; copper sulphate, 2.0; ferrous sulphate, 19.5; potassium iodide, 0.5 ; potassium chromium sulphate, 0.3 ; magnesium sulphate, 300.0; manganese sulphate, 7.5; sodium selenite, 0.02 ; zinc sulphate, 37; cellulose, 632.5 .

bVitamin premix consisted of ( $\mathrm{mg} / \mathrm{kg}$ of premix): thiamin hydrochloride, 10; riboflavin, 20; calcium pantothenate, 40; nicotinic acid, 50; pyridoxine hydrochloride, 10; folic acid, 5; inositol, 400; choline chloride, 2000; menadione, 10; cholecalciferol, 1500 IU; biotin, 1; vitamin B12, 0.02; vitamin A, $3000 \mathrm{IU}$; vitamin E, $50 \mathrm{IU}$; vitamin C, 200.

\section{Sample collection}

At the end of experiment, three carp were randomly selected from each tank, fasted overnight ( $24 \mathrm{~h}$ ) and then measured the body weight after anesthetized at a concentration of $100 \mathrm{mg} / \mathrm{L}$ in the diluted MS-222. The livers were frozen quickly in liquid nitrogen after weighed and then stored in $-80^{\circ} \mathrm{C}$ refrigerator. The liver samples were used for analysis of antioxidant enzymes activity and relate-genes expression, including heat shock protein70 (Hsp70), IL1- $\beta$, TNF- $\alpha$ and TGF- $\beta$.

\section{Growth measurements}

In this study, the growth performance index uses the following calculation formula: Survival rate $(\mathrm{SR}, \%)=100 \times$ (number of fish at the end/number of fish at the start of the experiment).

Hepatosomatic index $(\mathrm{HSI}, \%)=100 \times$ liver weight $(\mathrm{g}) /$ bodyweight $(\mathrm{g})$. 
Weight gain (WG, \%) $=100 \times$ (final body weight $(\mathrm{g})$ - initial bodyweight $(\mathrm{g})$ )/initial body weight $(g)$.

Feed conversion ratio $(F C R)=$ feed intake $(g) /$ weight gain $(g)$

Specific growth rate $(\mathrm{SGR}, \%$ per day) $=100 \times(\mathrm{Ln}$ final body weight $(\mathrm{g})$ - Ln initial body weight/ number of days).

\section{Antioxidant enzymes activity}

Antioxidant enzymes activity including Total antioxidant capacity (T-AOC), Catalase (CAT), Glutathione peroxidase activity (GPX), Superoxide dismutase (SOD) and Malondialdehyde (MDA).The antioxidant enzymes activity level of liver were analysed by the commercial assay kits produced by Nanjing Jiancheng Bioengineering (China).

\section{RNA extraction and determination of the expressions of immune-related genes}

A tissue homogenizer was used to homogenize approximately $50 \mathrm{mg}$ of quick-frozen liver samples from each animal. Total RNA was extracted using Trizol Reagen kit (Takara, Japan), the RNA quality was determined both by electrophoresis on an ethidium bromidestained $1.5 \%$ agarose gel and through the measurement of A260/A280 ratio. And $2 \mu \mathrm{g}$ of total RNA was reverse transcribed into cDNA using PrimeScript RT-PCR kit (Takara, Japan). RT-qPCR was carried out on CDNA samples for each of the treatments by RT-qPCR (SYBR Green II) on the Thermal Cycler Dice TP800 sequence detection system (Takara, Japan). The primer pairs were optimized for annealing temperature (Tm), each sample was run in triplicate and PCR reactions without template addition were used as negative controls. The reference gene $\beta$-actin was used as an internal control, which has been validated as a suitable reference gene for RT-qPCR normalization of tissue analysis of common carp. The $\beta$-actin expression was used to normalize the mRNA expression level of genes in each sample and was calculated using the $2^{-\Delta \Delta \mathrm{Ct}}$ method. Details of primers used for RT-qPCR are shown in Table 2.

Table 2 Sequences of primers for RT-qPCR

\begin{tabular}{|c|c|c|c|}
\hline Primers & $\begin{array}{l}\text { Primer } \\
\text { direction }\end{array}$ & Primer sequence $\left(5^{\prime} \rightarrow 3^{\prime}\right)$ & $\operatorname{Tm}\left({ }^{\circ} \mathrm{C}\right)$ \\
\hline HSP70 & $\begin{array}{l}\text { Forward } \\
\text { Reverse }\end{array}$ & $\begin{array}{l}\text { AAACAGACCCAGACCTTCAC } \\
\text { GTITAGTGATGAGTGGGTTGC }\end{array}$ & 52 \\
\hline IL-1- $\beta$ & $\begin{array}{l}\text { Forward } \\
\text { Reverse }\end{array}$ & $\begin{array}{l}\text { CGACTCTGATGAACTGGACTG } \\
\text { CCTCAAGTGTGAAGTTTGTGG }\end{array}$ & 54 \\
\hline TGF- $\beta$ & $\begin{array}{l}\text { Forward } \\
\text { Reverse }\end{array}$ & $\begin{array}{l}\text { GTCACGCTACCTGGAATCAC } \\
\text { CCACATAGTAAAAGATGGGCAG }\end{array}$ & 53 \\
\hline TNF-a & $\begin{array}{l}\text { Forward } \\
\text { Reverse }\end{array}$ & $\begin{array}{l}\text { TGAAGAAGGAGGATTGCTGC } \\
\text { CGAGATAAATCGTGTTGTACCAC }\end{array}$ & 52 \\
\hline$\beta$-actin & $\begin{array}{l}\text { Forward } \\
\text { Reverse }\end{array}$ & $\begin{array}{l}\text { ATCCGTAAAGACCTGTATGCCA } \\
\text { GGGGAGCAATGATCTTGATCTTCA }\end{array}$ & 55 \\
\hline
\end{tabular}

\section{Statistical analyses}

Data are presented as means with their standard errors. The statistical significance difference between treatments was assessed by SPSS v17.0 (SPSS Inc., Chicago, IL, USA) and One-way analysis of variance (ANOVA). The comparison between the treatments was considered significantly different $(P<0.05)$.

\section{Results}

\section{Growth performance}

Compared with the control, the specific growth rate of the fish fed feed supplemented with peony pollen significantly increased $(P<0.05)$, while the feed conversion rate of the fish fed feed supplemented with peony pollen significantly decreased $(P<0.05)$. In addition, significant differences were found among $3 \%$ and $2 \%$ and $4 \%$ groups. The highest specific growth rate, weight gain, final body weight and the lowest feed conversion rate 
were observed in fish fed $3 \%$ peony pollen. The survival rates of all groups were $100 \%$ (Table 3).

Table 3 Effects of dietary supplementation with peony pollen on growth parameters of common carp.

\begin{tabular}{|c|c|c|c|c|c|}
\hline \multirow{2}{*}{ Parameters } & \multicolumn{5}{|c|}{ peony pollen level } \\
\hline & $0 \%$ & $1 \%$ & $2 \%$ & $3 \%$ & $4 \%$ \\
\hline $\begin{array}{l}\text { Initial weight } \\
\text { (g) }\end{array}$ & $111.07 \pm 1.02$ & $113.42 \pm 2.01$ & $109.15 \pm 1.82$ & $112.06 \pm 2.46$ & $108.64 \pm 1.34$ \\
\hline $\begin{array}{l}\text { Final weight } \\
\text { (g) }\end{array}$ & $186.16 \pm 0.21^{a}$ & $194.24 \pm 1.41^{\mathrm{b}}$ & $212.32 \pm 0.74^{c}$ & $220.38 \pm 0.25^{c}$ & $198.86 \pm 0.57^{b}$ \\
\hline $\begin{array}{l}\text { Weight gain } \\
\text { (g) }\end{array}$ & $78.08 \pm 0.81^{a}$ & $85.67 \pm 1.01^{a}$ & $96.05 \pm 0.62^{b}$ & $\begin{array}{l}109.34 \pm 0.46 \\
c\end{array}$ & $91.25 \pm 0.68^{b}$ \\
\hline SGR $\left(\% d^{-1}\right)$ & $1.23 \pm 0.06^{a}$ & $1.29 \pm 0.01^{\mathrm{a}}$ & $1.58 \pm 0.04^{b}$ & $1.61 \pm 0.01^{\mathrm{b}}$ & $1.44 \pm 0.03^{\mathrm{b}}$ \\
\hline FCR & $2.05 \pm 1.02$ & $1.89 \pm 0.12^{\mathrm{b}}$ & $1.76 \pm 0.06 b$ & $1.63 \pm 0.07^{c}$ & $1.86 \pm 0.14^{b}$ \\
\hline HSI (\%) & $2.41 \pm 0.26$ a & $1.95 \pm 0.24^{b}$ & $2.19 \pm 0.32^{a}$ & $1.90 \pm 0.08^{b}$ & $1.97 \pm 0.45^{b}$ \\
\hline $\begin{array}{l}\text { Survival rate } \\
(\%)\end{array}$ & 100 & 100 & 100 & 100 & 100 \\
\hline
\end{tabular}

Note: Values expressed as means \pm SE. Different superscript letters indicate significant differences for each pairwise comparison between treatments $(P>0.05)$.

\section{Antioxidant enzymes activity}

As shown in Figure 1, compared with the control, the CAT and SOD levels showed significantly increased $(P<0.05)$ in fish fed $2 \%$ and $3 \%$ peony pollen. The T-AOC and GPX activity of fish fed peony pollen was significantly higher as compared to the control group $(P<0.05)$. However, the MDA activity was significantly decreased in peony pollen groups $(P<0.05)$.
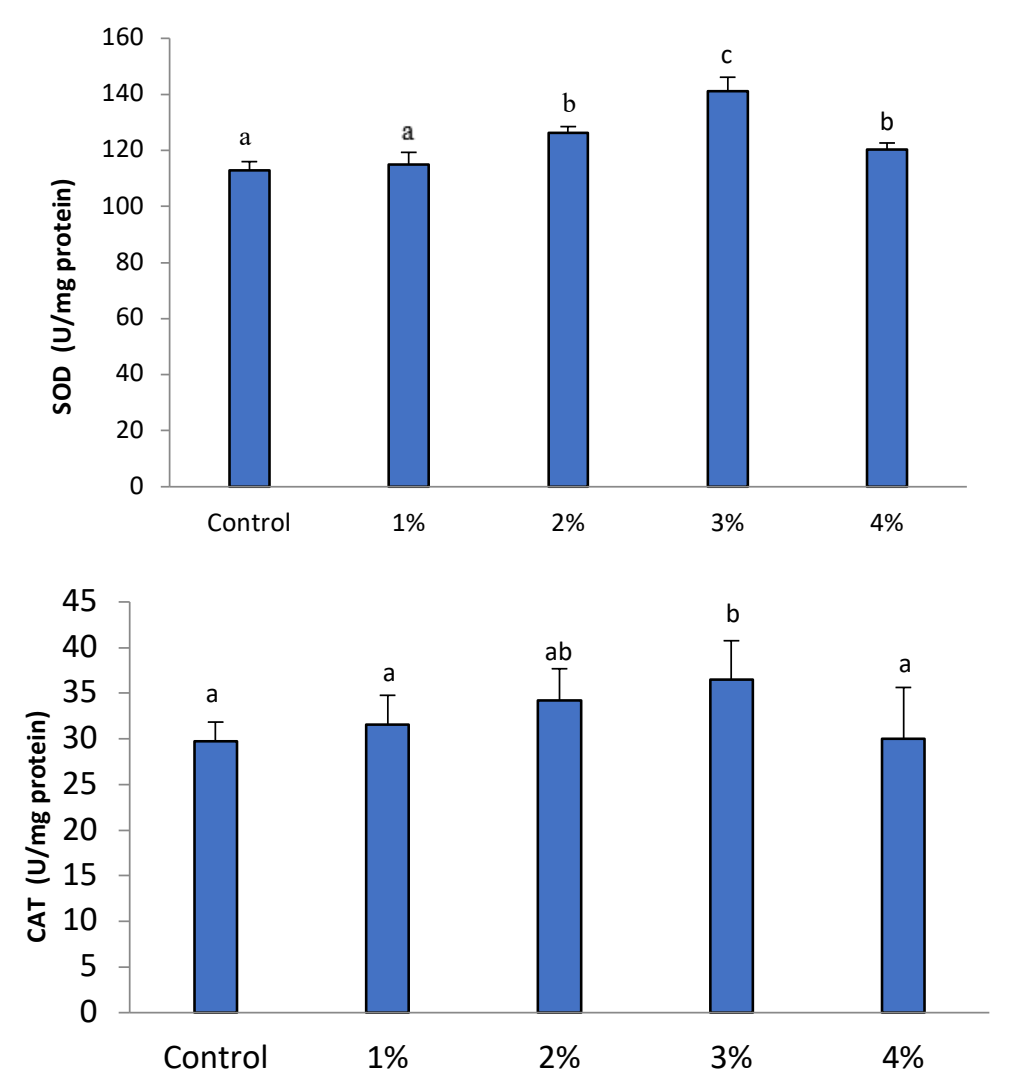

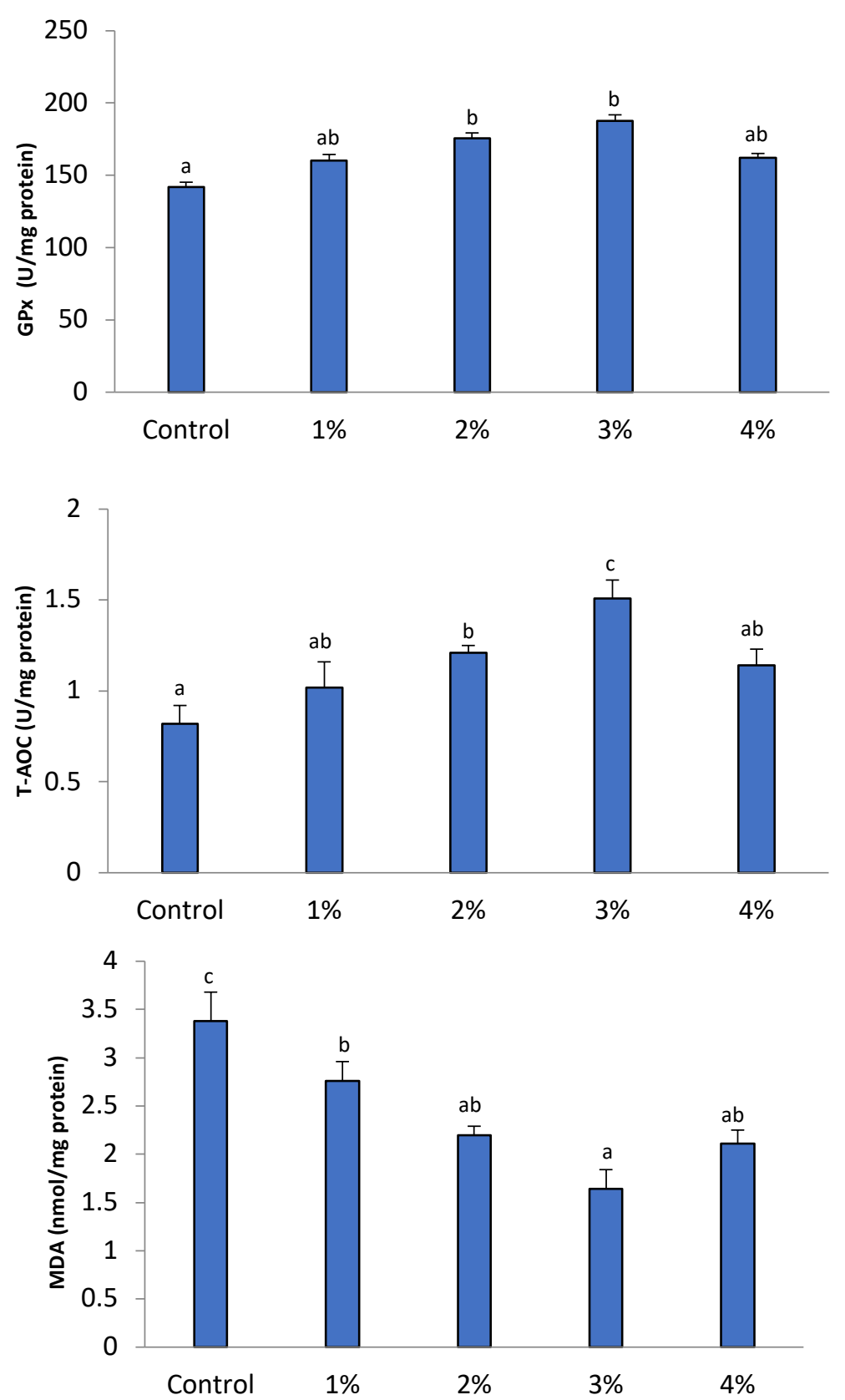

Figure 1 Antioxidant index responses of common carp $(n=9)$ fed test diets for 6 weeks. Values are expressed as mean $\pm \mathrm{SE}$ from triplicate groups. Bars with an asterisk are significantly different from those of control group $(P<0.05)$.

\section{Immune-related genes expression}

As shown in Figure $\mathbf{2}$ and Figure 3, after 6 weeks of trial, the gene expression of heat shock protein-70 (Hsp70) and cytokine genes (IL1- $\beta$, TNF- $a$, TGF- $\beta$ ) in the liver were analyzed using GPCR. Compared with the control, IL1- $\beta$, TNF- $\alpha$, TGF- $\beta$ were significantly decreased $(P<0.05)$ in peony pollen groups. The relative gene expression of Hsp70 was up-regulated significantly in peony pollen treatment groups $(P<0.05)$ (Figure 2$)$. 

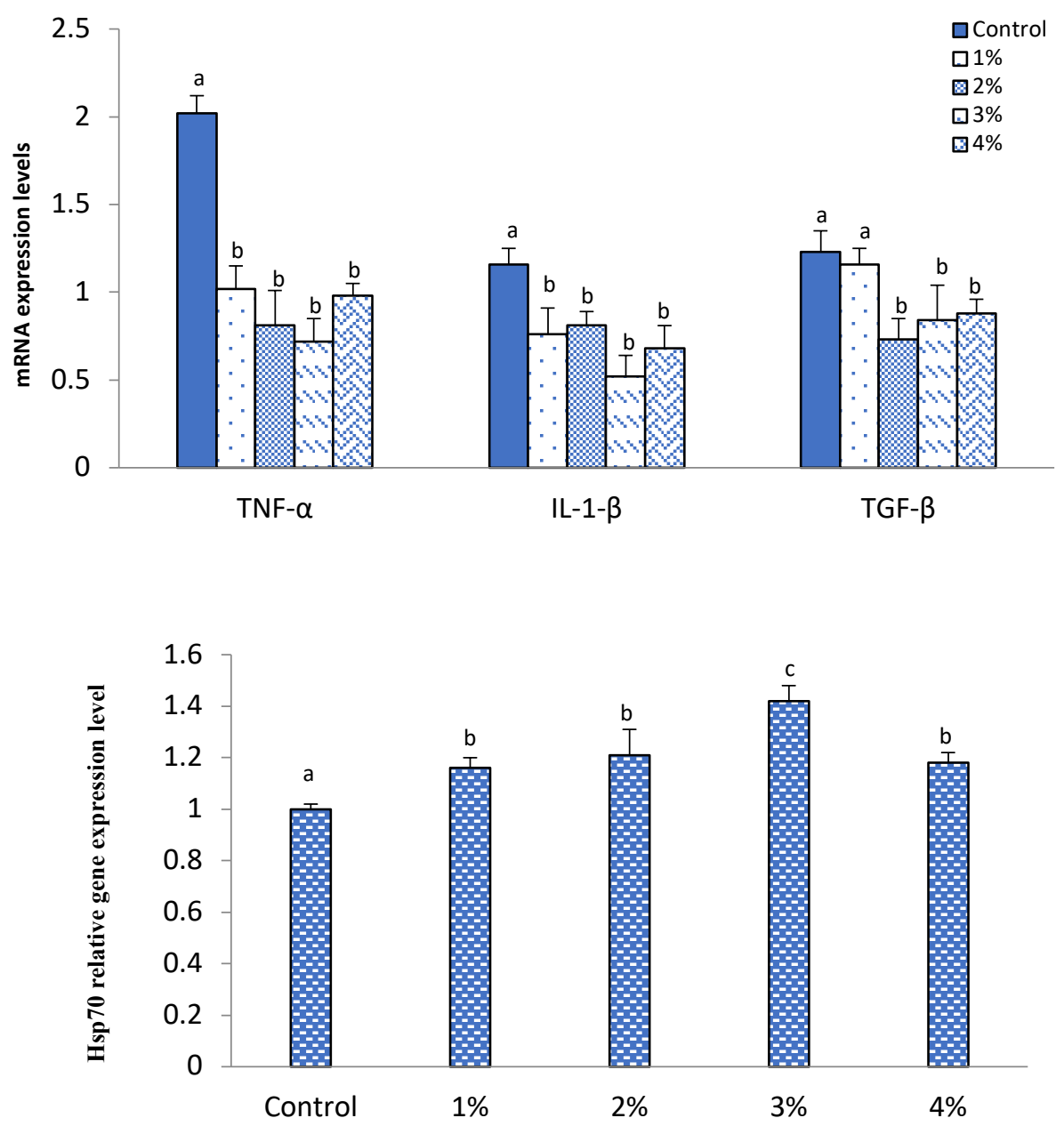

Figure 2 The mRNA transcription profiles of gene expression in liver of common carp $(n=9)$ after 6 weeks fed with different amount of dietary peony pollen. Values are means \pm SEM from triplicate groups. Different superscripts on each bar showed significantly different $(P<0.05)$.

\section{Discussion}

There are many kinds of useful components in the flower of peony pollen, among which flavonoids and polyphenols are the main active components, while anthocyanins have strong antioxidant activity and anti-tumor activity, It can inhibit tumor cell proliferation, metastasis and induce apoptosis of cancer cells. In addition, peony flower has great development and utilization value in nutrition, prevention and cure cardiovascular disease, anti-cancer, anti-arteriosclerosis, anti-aging and so on. Therefore, the medical application value of peony pigment anti-oxidation is expected and has broad prospects (Gao et al. 2011).

To date, there is no information on the possible effects of peony pollen on carps. In this study, a diet supplemented with $3 \%$ peony pollen could significantly increase the SGR and decrease the FCR of carps. These consistent results indicate that peony pollen diet can stimulate common carp growth performance. Peony pollen is rich in amino acids and vitamins, containing a large number of health-care functions of polysaccharides (Yuan et al., 2013). This result suggests that peony pollen may be a candidate for a potential feed additive in aquaculture. The application of peony pollen in aquaculture needs further extensive and in-depth study.

Like terrestrial animals, the fish have evolved non-enzymatic and enzymatic antioxidant systems to protect organisms from oxidative damage (Martínez-Álvarez et al., 2005). TAOC, CAT, SOD and GPx are important antioxidant enzymes. During normal metabolism of the organism, antioxidant enzymes is by catalyzing the disproportionation of two 
superoxide radicals into oxygen $\left(\mathrm{O}_{2}\right)$ and hydrogen peroxide $\left(\mathrm{H}_{2} \mathrm{O}_{2}\right)$ to remove harmful reactive oxygen species (ROS) from the cellular environment (Aliko et al., 2018; Gobi et al., 2018). Therefore, SOD, CAT, GPX and T-AOC, besides being markers of oxidative stress, can also be used to evaluate the antioxidant capacity of aquatic organisms (Apel and Hirt, 2004; Dawood et al., 2019; Gaetani et al., 1996). Too much free radicals can lead to Lipid peroxidation. MDA is a major component of products of oxidative stress. (Ming et al., 2012). T-AOC, CAT, SOD and GPx can reducing the toxicity of ROS by scavenge excess free radicals (Sies, 1997). Our results indicate that fish fed peony pollen are more active in SOD, CAT, GPX, and T-AOC than fish fed control feeds, indicating reduced cell damage. Among them, the antioxidant enzyme level of $3 \%$ peony pollen group shows significantly higher than that of the control group. Previous studies have also shown that prebiotic feeding can increase SOD, CAT, GPX and T-AOC levels (Dawood et al., 2015; Ahmadifar et al., 2019). The authors believe that there may be some biologically active substances in Chinese herbal medicine, which may increase the animal's antioxidant activity and regulate the reactive oxygen species intermediate system. The results of this test show that peony pollen can significantly activate the antioxidant activity of carp, effectively remove excess free radicals in the body, adjust the active oxygen balance, and thereby improve the antioxidant capacity. at the same time, the results revealed that peony pollen has acute phase protein stimulating and anti-inflammatory effects on carp, and the antioxidant enzyme gene has a tendency to increase.

In order to further explore the molecular mechanism of peony pollen to improve the antioxidant activity of common carp, the mRNA expression levels of immune-related genes in the livers of common carp were measured. The results showed that the cytokine genes of common carp were decreased by feeding peony pollen. The peony pollen diets lowered the genes for anti-inflammatory cytokines (IL1- $\beta$ and TNF- $\alpha$ ) and pro-inflammatory cytokine (TGF- $\beta$ ), ensuring the balance of cytokine genes in fish. Excessive or persistent inflammation is harmful to fish. Therefore, the cytokine gene changes in this study did not affect the balance of carp. Induced Hsp70 has multiple functions, such as synergetic immunity, antioxidants, molecular chaperone and anti-apoptosis (Daugaard et al., 2007), can increase cell viability, maintain cell homeostasis, and increase resistance to hostile environments or pathogens (Feder and Hofmann, 1999). Up to now, there is no report about the effect of peony pollen on the hsp70 in common carp liver. In this study, the Hsp70 expression level increased with the increase of peony pollen content in the diet. The results showed that the content of Hsp70 can be effectively increased by feeding certain amount of peony pollen, which is beneficial to improve the ability of anti-stress.

\section{Conclusions}

In summary, it is still one of the key works for aquatic workers to search for new functional feed resources. In the study, our observations suggest that $3 \%$ peony pollen supplementation in the diets has the potential to improve the immune response by activating carp's cellular antioxidant activity and regulating the expression of relatedimmune genes, which may lead to increased carp tolerance to adverse conditions. Further research is needed on the use of peony pollen to improve disease resistance in fisheries.

\section{Acknowledgements}

This research was supported by Henan Natural Science Foundation (182300410032).

\section{References}

Ahmadifar, E., Moghadam, M., Dawood, M. and Hoseinifar, S. H. $2019 . \quad$ Lactobacillus fermentum and/or ferulic acid improved the immune responses, antioxidative defence and resistance against Aeromonas hydrophila in common carp (Cyprinus carpio) fingerlings. Fish Shellfish Immunol ., 94, 916-923. https://doi.org/10.1016/j.fsi.2019.10.019 
Aliko, V., Qirjo, M., Sula, E., Morina, V. and Faggio, C. 2018. Antioxidant defense system, immune response and erythron profile modulation in gold fish, Carassius auratus, after acute manganese treatment. Fish Shellfish Immunol., 76, 101-109. https://doi.org/10.1016/j.fsi.2018.02.042

Apel, K. and Hirt, H. 2004. Reactive oxygen species: metabolism, oxidative stress, and signal transduction. Annu. Rev. Plant Biol., 55, 373-399. DOI: 10.1146/annurev.arplant.55.031903.141701 Bao, L., Chen, Y., Li, H., Zhang, J., Wu, P., Ye, K. and Ai, H. 2019. Dietary Ginkgo biloba leaf extract alters immune-related gene expression and disease resistance to Aeromonas hydrophila in common carp Cyprinus carpio. Fish Shellfish Immunol., 9479, 810-818. https://doi.org/10.1016/j.fsi.2019.09.056

Bulfon, C., Volpatti, D. and Galeotti, M. 2015. Current research on the use of plant-derived products in farmed fish. Aquacult. Res., 46, 513-551. https://doi.org/10.1111/are.12238

Daugaard, M., Rohde, M. and Jäättelä, M. 2007. The heat shock protein 70 family: highly homologous proteins with overlapping and distinct functions. FEBS Lett., 581, 3702-3710. DOI: 10.1016/j.febslet.2007.05.039

Dawood, M.A.O. and Koshio, S. 2016. Recent advances in the role of probiotics and prebiotics in carp aquaculture: a review. Aquaculture, 454, 243-251. https://doi.org/10.1016/j.aquaculture.2015.12.033

Dawood, M.A.O., Koshio, S., Ishikawa, M. and Yokoyama, S. 2015. Effects of heat killed Lactobacillus plantarum (LP20) supplemental diets on growth performance, stress resistance and immune response of red sea bream, Pagrus major. Aquaculture, 442, 29-36. https://doi.org/10.1016/j.aquaculture.2015.02.005

Dawood, M.A.O., Koshio, S., Zaineldin, A.I., Van Doan, H., Moustafa, E.M. and Abdel-Daim, M.M. 2019. Dietary supplementation of selenium nanoparticles modulated systemic and mucosal immune status and stress resistance of red sea bream (Pagrus major). Fish Physiol. Biochem., 45, 219-230. https://doi.org/10.1007/s10695-018-0556-3

Cañada-Cañada. F., Munozde, la Pena. A. and Espinosa-Mansilla, A. 2009. Analysis of antibiotics in fish samples. Anal. Bioanal. Chem., 395, 987-1008. https://doi.org/10.1007/s00216009-2872-z

El-Haroun, E. R., Goda, A.M.A.S. and Chowdhury, M.A.K. 2006. Effect of dietary probiotic Biogen (R) supplementation as a growth promoter on growth performance and feed utilization of Nile tilapia Oreochromis niloticus (L). Aquaculture Research, 37, 1473-1480. https://doi.org/10.1111/j.13652109.2006.01584.x

Feder, M. and Hofmann, G. 1999. Heat-shock proteins, molecular chaperones, and the stress response: evolutionary and ecological physiology. Annu. Rev. Physiol., 61, 243-282. https://doi.org/10.1146/annurev.physiol.61.1.243

Gaetani, G., Ferraris, A., Rolfo, M., Mangerini, R., Arena, S. and Kirkman, H. 1996. Predominant role of catalase in the disposal of hydrogen peroxide within human erythrocytes. Blood, 87,1595-1599. https://doi.org/10.1182/blood.V87.4.1595.bloodjournal8741595

Galina, J., Yin, G., Ardo, L. and Jeney, Z. 2009. The use of immunostimulating herbs in fish. An overview of research. Fish Physiol. Biochem, 35, 669-676. https://doi.org/10.1007/s10695-0099304-z

Gao, Y., Zhang, S., Zhang, S. and Wan, S. 2011. Research progress on composition and application of peony. Journal of Henan University of Technology, 32, 93-96. https://doi.org/CNKI:411378/N.20111220.1501.019

Gobi, N., Vaseeharan, B., Rekha, R., Vijayakumar, S. and Faggio, C. 2018. Bioaccumulation, cytotoxicity and oxidative stress of the acute exposure selenium in Oreochromis mossambicus. Ecotoxicol. Environ. Saf., 162, 147-159. https://doi.org/10.1016/j.ecoenv.2018.06.070

Jian, J. and $\mathbf{W u}$, Z. 2004. Influences of traditional Chinese medicine on non-specific immunity of Jian Carp (Cyprinus carpio var. Jian). Fish Shellfish Immunol., 16, $185-191$. https://doi.org/10.1016/S1050-4648(03)00062-7

Liu, J., Li, N. and Wang, C. 2012. Study on extraction and antioxidant activity of flavonoids from Peony Pollen. Food Research and development, 33, 39-44.

Makkar, H. P. S., Francis, G. and Becker. K. 2005. Bioactivity of phytochemicals in some lesserknown plants and their effects and potential applications in livestock and aquaculture production systems. Animal, 1, 1371-1391. https://doi.org/10.1017/S1751731107000298

Martínez-Álvarez, R., Morales, A. and Sanz, A. 2005. Antioxidant defenses in fish: biotic and abiotic factors. Rev. Fish Biol. Fish, 15, 75-88. https://doi.org/10.1007/s11160-005-7846-4

Ming, J., Xie, J., Xu, P., Ge, X., Liu, W. and Ye, J. 2012. Effects of emodin and vitamin $C$ on growth performance, biochemical parameters and two HSP70s mRNA expression of Wuchang bream (Megalobrama amblycephala Yih) under high temperature stress. Fish Shellfish Immunol., 32, 651661. https://doi.org/10.1016/j.fsi.2012.01.008 
Naylor, R.L., Goldburg, R.J., Primavera, J.H., Kautsky, N., Beveridge, M.C.M., Clay, J., Folke, C., Lubchenco, J., Mooney, H. and Troell, M. 2000. Effect of aquaculture on world fish supplies. Nature, 405, 1017-1024. https://doi.org/10.1038/35016500

Ramos, M.A., Batista, S., Pires, M.A., Silva, A.P., Pereira, L.F., Saavedra, M.J., Ozorio, R.O.A. and Rema, P. 2017. Dietary probiotic supplementation improves growth and the intestinal morphology of Nile tilapia. Animal, 11, 1259-1269. DOI: $10.1017 /$ S1751731116002792

Sharma, K.R. and Leung, P. 2000. Technical efficiency of carp pond culture in South Asia: an application of a stochastic meta-production frontier model. Aquacult. Econ. Manag, 4, 169-189. https://doi.org/10.1080/13657300009380268

Sies, H. 1997. Oxidative stress: oxidants and antioxidants. Exp. Physiol. 82, 291-295. https://doi.org/10.1113/expphysiol.1997.sp004024

Van Doan, H., Hoseinifar, S.H., Dawood,M.A.O., Chitmanat, C. and Tayyamath, K. 2017. Effects of Cordyceps militaris spent mushroom substrate and Lactobacillus plantarum on mucosal, serum immunology and growth performance of Nile tilapia (Oreochromis niloticus). Fish Shellfish Immunol., 70, 87-94. https://doi.org/10.1016/j.fsi.2017.09.002

Van Hai, N. 2015. The use of medicinal plants as immunostimulants in aquaculture: a review. Aquaculture, 446, 88-96. https://doi.org/10.1016/j.aquaculture.2015.03.014

Van Hai, N. 2015. Research findings from the use of probiotics in tilapia aquaculture: a review. Fish Shellfish Immunol., 45, 592-597. https://doi.org/10.1016/j.fsi.2015.05.026

Yuan, Y., Wang, C. and Rao, H. 2013. Research progress of flavonoid in peony flowers. Journal of the Qilu University of Technology, 4, 31-34. 